\title{
Correction to: An intelligent personalized web blog searching technique using fuzzy-based feedback recurrent neural network
}

\author{
Harsh Khatter ${ }^{1} \cdot$ Anil Kumar Ahlawat ${ }^{2}$
}

Published online: 29 April 2020

(C) Springer-Verlag GmbH Germany, part of Springer Nature 2020

\section{Correction to:}

\section{Soft Computing}

https://doi.org/10.1007/s00500-020-04891-y

While typesetting the article, the surname of the second author has been incorrectly published. The correct name has been given below:

Anil Kumar Ahlawat

The original article has been corrected.

Publisher's Note Springer Nature remains neutral with regard to jurisdictional claims in published maps and institutional affiliations.

The original article can be found online at https:// doi.org/10.1007/s00500-020-04891-y.

\section{Harsh Khatter}

HarshKhatter@yahoo.com

1 Department of Computer Science and Engineering, ABES Engineering College, AKTU, Lucknow, India

2 Department of Computer Science and Engineering, KIET Group of Institutions, Ghaziabad, Uttar Pradesh, India 